\title{
BUILDING COMPLEX OF RIVNE REGION: HUMAN-GEOGRAPHICAL STUDY
}

\author{
Kateryna KYCHA, 'Artem KYCHA \\ Taras Shevchenko National University of Kyiv, Ukraine \\ 'ndkaa@inbox.ru
}

\begin{abstract}
The paper presents the study of the basic processes of territorial organization of the regional construction industry such as location, concentration, integration, industry-territorial structuring. As a result, the industrial structure of complex and the distribution of branches within the region has been examined; the main enterprises of construction complex and conditions of their functioning has been identified.

The actuality of the common research is determined, firstly, by the necessity to answer the key question of discussion according to competitive economic activities, being the driver of the regional economy, secondly, by the attempt to determine the conditions of formation of the industrial branches of specialization and their role in the regional economic system.

The aim of the article is to determine the characteristics of sectoral and territorial structure of the building complex of Rivne region, to reveal characteristics of the main enterprises producing construction materials, conditions of their formation and the value of industrial products. Also important is the study of raw materials affecting the development of the construction industry.

Theoretical and practical results of the research were achieved by using the following general and specific methods: interdependence and correlation, causality, structural analysis, mapping, field studies, and statistical literature.

Consequently, the paper explores construction industry of Rivne region, defines preconditions of its formation and features of industry-territorial structure, investigates the main enterprises producing construction materials and their role for the industry of the region. Moreover, human-geographical research has defined construction industry sector as a branch of regional specialization.
\end{abstract}

Key words: building complex, industry, manufacturing, deposits, value of industrial products.

UDC: 911.3

\section{СУСПІЛЬНО-ГЕОГРАФІЧНЕ ДОСЛІДЖЕННЯ БУДІВЕЛЬНОГО КОМПЛЕКСУ РІВНЕНСЬКОÏ ОБЛАСТІ}

\author{
Катерина КИЧА, 'Артем КИЧА \\ Київський начіональний університет імені Тараса Шевченка, Україна \\ 'ndkaa@inbox.ru
}

Анотація: У статті представлено дослідження основних процесів територіальної організації обласного будівельного комплексу таких як: розміщення, зосередження, інтеграція, галузево-територіальна структуризація. У результаті, вивчено галузеву структуру вищевказаного комплексу, розміщення галузей в межах адміністративної області, виділено основні підприємства промисловості будівельних матеріалів та передумови їх функціонування.

Актуальність спільного дослідження визначається, по-перше, необхідністю відповісти на ключове питання дискусії щодо конкурентоспроможних видів економічної діяльності, драйверу економіки в регіоні, по-друге, спробою визначити умови формування та роль галузей спеціалізації в регіональній економічній системі.

Метою статті $\epsilon$ визначення особливостей галузевої та територіальної структури будівельного комплексу Рівненської області, характеристика основних підприємств промисловості будівельних матеріалів, умов їх формування та частки у вартості реалізованої промислової продукції. Також важливим $\epsilon$ дослідження сировинної бази, що впливає на розвиток будівельного комплексу.

Теоретичні і практичні результати були досягненні за допомогою використання наступних загальнонаукових та спеціальних методів: взаємообумовленості та взаємозв'язку, причинності, структурний аналіз, картографічний метод, метод польових досліджень, статистичний та літературний.

Отже, в статті досліджена будівельна промисловість Рівненської області, визначено передумови їі формування, особливості територіально-галузевої структури, виділено основні підприємства виробництва будівельних матеріалів та їх роль у промисловості регіону. Більш того, в процесі суспільно-географічного дослідження, будівельну галузь промисловості визначено галуззю спеціалізації досліджуваної області.

Ключові слова: будівельний комплекс, промисловість, виробництво, родовища, вартість реалізованої промислової продукції.

\section{удк: 911.3}

Вступ. Постановка проблеми. Будівельний комплекс об'єднує систему підприємств і галузей, продукція яких призначається для капітального будівництва у сферах промисловості, сільського господарства, транспорту, а також для потреб

(C) К. Кича, А. Кича житлово-комунального господарства та всіх інших сфер людської діяльності [3, с. 168]. Незважаючи на високу залежність від зміни фаз в економіці, він $є$ інвестиційно привабливим видом економічної діяльності й може стати драйвером, що здатний подолати кризовий стан і забезпечити сталий розвиток. При дослідженні галузево- 
територіальної структури будівельного комплексу необхідно враховувати наявність та видобуток мінерально-будівельної сировини, що впливає на спеціалізацію та зосередження його елементів.

Аналіз останніх досліджень і публікацій. Дослідженням територіальної організації будівельного комплексу займались О.В. Гладкий, C. І.Іщук， О. І.Шаблій， Й.А.Бурка， В.Й.Бурка та ін. Значний внесок у вивчення промисловості будівельних матеріалів Рівненської області зробили К.І.Геренчук, I.M.Коротун, Л.К.Коротун, Г.І.Купалова. В їхніх працях детально аналізуються наявність сировини, процеси розміщення підприємств будівельної галузі області, проблеми та перспективи розвитку.

Формулювання цілей статті. Постановка завдання. Метою дослідження $є$ виявлення особливостей галузевої та територіальної структури будівельного комплексу Рівненської області, характеристика основних підприємств промисловості будівельних матеріалів.

Виклад основного матеріалу. Комплекс виробництва будівельних матеріалів на Рівненщині $є$ досить розвинутим. У даному напрямку здійснюють діяльність двадцять дев’ять підприємств та безліч ФОП. Відповідно до КВЕД продукція даної галузі відноситься до коду 23 «Виробництво іншої неметалевої мінеральної продукції» та 8.01 «Добування каменю, піску та глини».

Рівненська область характеризується порівняно значними покладами базальту, граніту, піску, вапняку, глини, габро та інших мінеральних ресурсів.

Базальт у області добувають на шести родовищах: у Володимирецькому районі Рафалівське та Полицьке II, у Костопільському - Великомидське, Берестовецьке, Берестовецьке-І та Івано-Долинське.

Родовища граніту у області $\epsilon$ найбільш поширеними. Переважна більшість покладів сконцентрована у Сарненському та Рокитнівському районах. Найбільшими родовищами граніту у Рівненській області є: у Корецькому районі - Корецьке та Жадківське; у Рокитнівському - Рокитнівське, Крута Слобода, Пщілля, Кіндратівське, Сновидовицьке, Клесівське-III; у Сарненському - Клесівське-2, Клесівське-6, Вирівське, Вирівське-2, Клесівське «Купчина», Селищанське-1, Ясногірське, Селищанське-2, Яблунівське, Олексіївське-1.

Найбільшими родовищами гранодіоритів є Томашгородське-3 (Рокитнівський район), Клесівське-1 та Клесівське-7 (Сарненський район).

Високими темпами експлуатуються i родовища піску: у Володимирецькому районі Сопачівське; у Дубровицькому - Велюнське; у Здолбунівському - Здовбицьке та Коршівське; у Костопільському - Малолюбашанське, Малолюбашанське-2, Борковецьке; в Острозькому
- Вельбівненське; у Рівненському - Любомирське, Метківське; у Рокитнівському - Скопані Гори, Рокитнівське-2; у Сарненському - Немовицьке.

Родовища вапняку зосереджені на півдні області: у Дубенському районі - Семидубське-2, Грядківське, Варковицьке; в Острозькому Батьківське.

Також у південній частині області розташовані родовища крейди: у Здолбунівському районі - Здолбунівське; у Дубенському - Мильчанське; у Млинівському - Торговицьке; у Рівненському Любомирське.

Основні поклади глини розташовані у Гощанському (Заруднянське родовище), Костопільському (Жалянське, Костопільське), Дубровицькому районах (Сварицевицьке).

Також у Рівненській області видобувають габро, єдине родовище якого знаходиться у Рокитнівському районі (Кисорицьке).

Значними в області є поклади суглинків. Їхнє видобування ведеться у таких районах: Березнівському (Хотинське родовище), Гощанському (Гощанське), Дубенському (Загірцівське), Здолбунівському (Здолбунівське), Корецькому (Богданівське), Млинівському (Залав'ївське, Брищанське; Острозький район Острозьке [1].

Незважаючи на велику кількість родовищ, далеко не всі вони розробляються. Видобуток i первинна обробка мінерально-будівельної сировини представлені в області численними кар'єрами та підприємствами, які здійснюють подрібнення, шліфування, транспортування видобутої з надр сировини.

Особливе місце в галузі посідають кар'єри, де розробляються кристалічні (магматичні та метаморфічні) породи i які розташовуються на західній окраїні Українського щита (Рокитнівський, Сарненський, Березнівський райони) та вздовж ліній давніх розломів. Так, до щита приурочені підприємства по видобутку гранітів, гранодіоритів, мігматитів, які діють у смт Томашгород (тут знаходиться чотири щебеневих кар'єри різного підпорядкування), смт Клесів (спецкар'єр та щебеневий кар'єр), Рокитному (спецкар'єр). Помітне місце у галузі посідають Ярівський та Соснівський гранкар'єри.

Найбільшими підприємствами за вартістю реалізованої продукції у 2014 році були Клесівський кар'єр нерудних копалин «Технобуд» (281 млн грн у 2014 р.), що посідає за даним показником 10 місце у області, та Вирівський кар'єр (130 млн грн у 2014 р.), які разом забезпечують $65 \%$ вартості реалізованої промислової продукції (далі - в.р.п.п.) Сарненського району.

Поряд 3 гранітоїдами Українського щита в області ведеться розробка базальтів, на якій спеціалізуються Іваново-Долинський кар'єр у с.Базальтове та Берестовецький спецкар'єр у Костопільському районі, де виготовляється не тільки щебінь, що йде на будівництво поліських автошляхів Волині та Рівненщини, але $є$ плити 
та блоки різного призначення (спорудження меморіалів, виготовлення бордюрів тощо).

Крім згаданих підприємств, що здійснюють видобуток i первинну обробку кристалічних порід, вагоме місце у галузі посідають численні кар'єри по розробці напівскельних та пухких порід (вапняків, пісковиків, крейди, мергелів, глин, суглинків, пісків). Проте більшість 3 них тісно пов'язана 3 переробними підприємствами будівельного комплексу (цементні, цегельні та інші заводи).

Галузь виробництва будівельних матеріалів в Рівненській області базується на місцевій сировині, відповідно розвиток галузі тісно пов'язаний із розвитком добувної промисловості та тенденціями будівництва області. На території області знаходиться одне $з$ найбільших в Україні підприємств 3 виробництва цементу, а також провідні заводи-виробники скла та скляної продукції (в основному для потреб харчової промисловості).

За підсумками 2014 року на фоні подальшого зниження продукції в загальному по Україні на 9\%, в Рівненській області спостерігалося зростання в розмірі 0,9\%. Питома вага експорту виробів з каменю, гіпсу, цементу, кераміки, скла у загальному обсязі експорту товарів Рівненської області становила 8,2\%. Основною експортною статтею є скло та вироби із скла - 33 млн. дол. США (91,8\% від загального експорту виробів 3 каменю, гіпсу, цементу, кераміки, скла). У загальному обсязі імпортованих у Рівненську область товарів будматеріали 3 каменю, гіпсу, цементу, кераміки, скла становили близько 5,2\%. Основними статтями імпорту, як і у випадку із експортом, були скло та вироби із скла - 9,9 млн. дол. США (74\% імпорту продукції галузі).

Виробництво скла та виробів зі скла. У Рівненській області в даній галузі, що почала формуватися на базі місцевих родовищ кварцових пісків, працюють чотири підприємства. Найбільшим представником даної галузі за обсягами виробленої продукції $є$ ПрАТ «Консюмерс-Скло-Зоря» із показниками в.р.п.п. у 2014 році 652,2 млн грн (7 місце у області), що забезпечує $35 \%$ в.р.п.п. Рівненського району. Підприємство є прибутковим (4 млн грн у 2014 році, хоча у 2013 мав збитків у 28 млн грн).

ПрАТ «Консюмерс-Скло-Зоря» заснований у 1973 році з метою консервації власної плодоовочевої продукції. 32005 року стає частиною французької компанії Saint-Gobain в межах сектору упаковки. Зараз власником є німецька компанія. Завод є одним з лідерів по виробництву склотари в Україні. Виробляють високоякісну тару марки БТ та Extra flint (безкольорове тонке). Першими в Україні почали виготовляти полегшену тару марки NNPB (легша на 30\% при тих же характеристиках). Завод може виготовляти до 600 т скла на добу і у 2014 році виготовив 138 тис т ємностей зі скла.Виготовляють склотару для таких компаній: «Kraft Foods» (зараз «Mondelez
International»), «Чумак», «Руна», «СоюзВіктан», «Nemiroff». Форми для виготовлення імпортуються 3 Європи та Китаю. Піддони постачаються з Клевані, стрейчева плівка - iз Здолбунова. Трудові ресурси складають 570 осіб, в основному з Рівненського району та м. Рівне. Навчального центру немає.

ПрАТ «Костопільський завод скловиробів» забезпечує 18,7\% в.р.п.п. району (236 млн грн у 2014 р.), проте у 2014 році підприємство стало збитковим (8,6 млн грн). Чверть акцій підприємства належить британській компанії. ПрАТ «Костопільський завод скловиробів», виробляє скляні ємності від 20 мл до 2 л. Пісок постачається 3 Харківської області. Доломіт та вапняк - 3 Тернопільської. Сода, сульфат, окис кобальту та селен - 3 Білорусії та Польщі. Поліетиленову плівку постачає Здолбунівський завод «Квант». Картон купують в Обухові та Жидачеві. Форми імпортують 3-за кордону - 3 Болгарії та Чехія. Продукція заводу використовується в парфумерії, медицині та харчовій промисловості (22-24\% продукції експортується).

Рокитнівський завод скловиробів був заснований ще у 1898 році бельгійцем. Зараз на заводі працює 472 особи і у 2014 ним було реалізовано продукції на суму 228 млн грн, що забезпечує 70\% в.р.п.п. району. У 2014 році підприємство зазнало збитків у розмірі 130 млн грн.

Основним видом продукції, що випускає завод, є склотара (як стандартних зразків, так i ексклюзивних), в основному це пляшки в зеленому та коричневому кольорі скла місткістю від 0,2 до 1,0 літра, які використовуються для пивних заводів, заводів по виготовленню безалкогольних напоїв, а також заводів шампанських вин. Продукція заводу відповідає європейським стандартам якості i здатна задовольнити найвибагливіші смаки. Основними споживачами продукції ПрАТ «Рокитнівський скляний завод» є: ПАТ «Оболонь» (м. Київ), ПАТ «Карлсберг Україна» (м. Запоріжжя), ПАТ «САН ІнБев Україна» (м. Київ), ТзОВ ТВК «Перша приватна броварня» (м. Львів), ПАТ «ПБК «Радомишль» (м. Радомишль), ПрАТ «Моршинський ЗМВ «Оскар» (м. Моршин), ТОВ «Котнар-М» (с. Мужієво, Закарпатська обл.), ТОВ «Аква-Поляна» (с. Поляна, Закарпатська обл.), ТДВ «Свалявські мінеральні води» (м. Свалява, Закарпатська обл.), ПрАТ «Одесавинпром» (м.Одеса), ПрАТ «Ізмаїльський виноробний завод» (м. Ізмаїл, Одеська обл.), ТзОВ «Одеський ЛГЗ» (м. Одеса), ПрАТ «Рівень» (м. Рівне), ТОВ «Бердичівський пивзавод» (м. Бердичів), ТОВ «Пивоварня «Опілля» (м. Тернопіль), ПАТ «Хмельницький обласний пивзавод» (м. Хмельницький), обсяг реалізації продукції для яких становить майже $100 \%$ від загального обсягу реалізованої продукції.

Для виробництва скляної тари завод використовує наступні компоненти: сода 


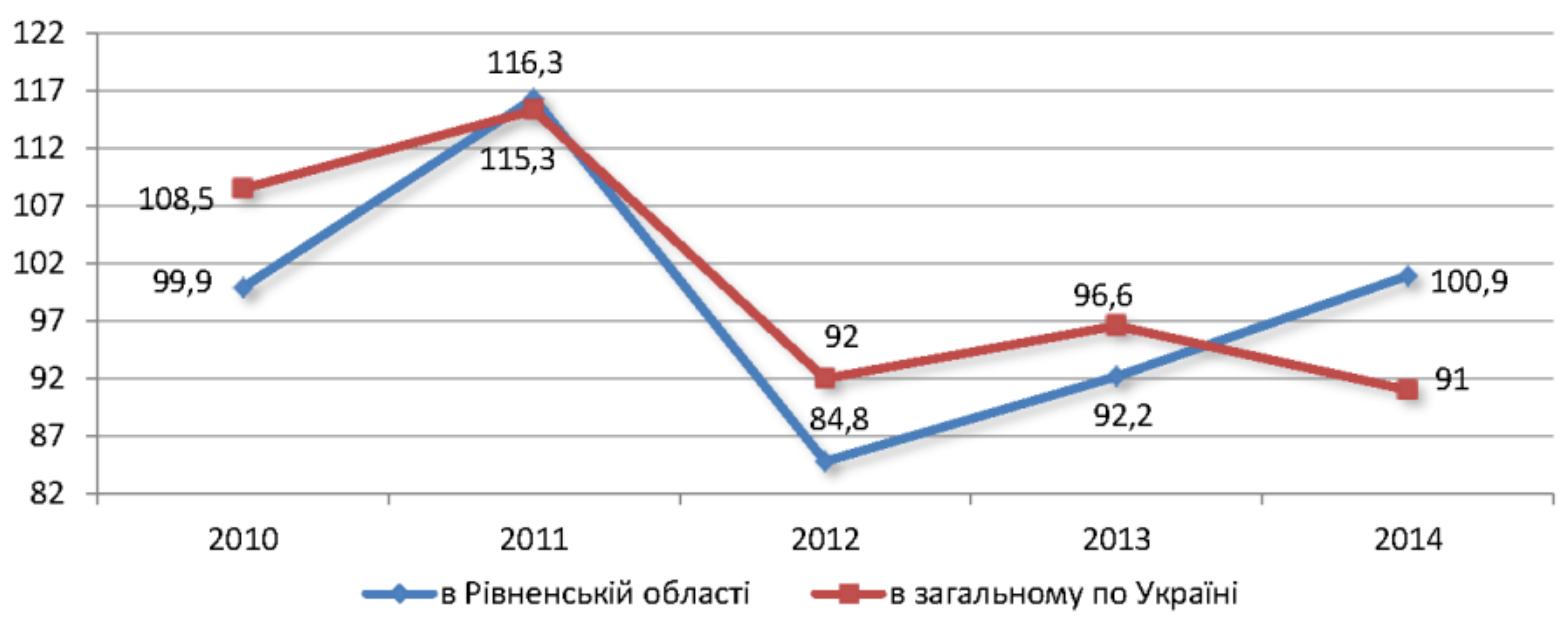

Рис.1. Індекси виробництва іншої неметалевої мінеральної продукції в Рівненській області та в загальному по Україні у 2010-2014 роках, \%, (побудовано автором за [2])

Виробництво продукції промисловості будівельних матеріалів у 2014 р., тис грн

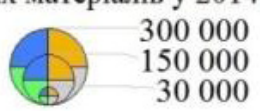

$\square$ підприємства, відомості про вартість реалізованої продукції яких відсутні

виробництво скла та виробів зі скла виробництво будівельних матеріалів із глини виробництво цементу, вапна та гіпсових сумішей

$\square$ виготовлення виробів із бетону, гіпсу та цементу

різання, оброблення та оздоблення декоративного та будівельного каменю

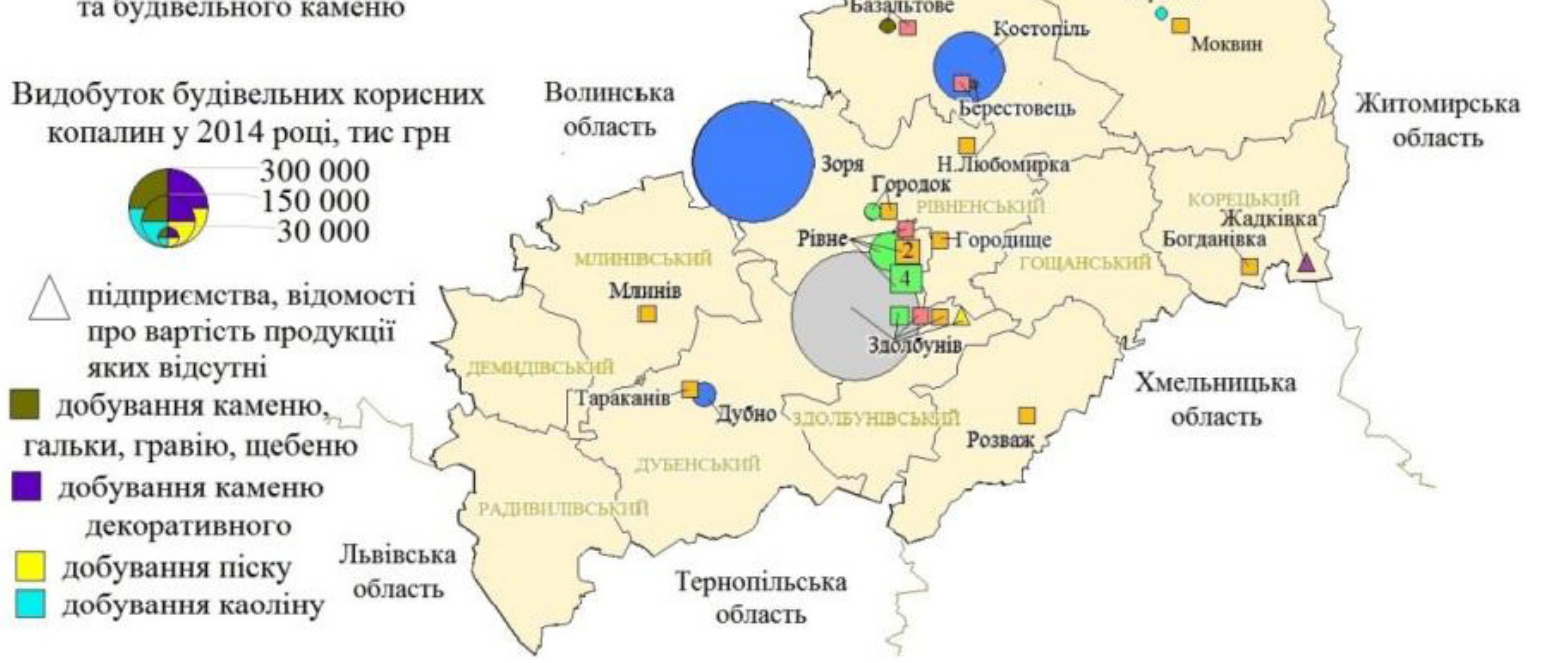

Рис.2. Підприємства промисловості будівельних матеріалів у Рівненській області (побудовано автором за [2]) 
кальцинована, доломіт, глинозем, сульфат натрію, селітра натрієва, пісок, склобій та інше. Основні види сировини, які використовуються на виробництві, постачаються в основному вітчизняними розробниками надр та виробниками необхідної для виробництва продукції. Сульфат натрію постачає Росія, кальциновану соду - АР Крим.

Виробництво будівельних матеріалів із глини у порівнянні із іншими напрямками найбільш широко представлене по території області. У даній сфері діє тринадцять підприємств області, що спеціалізуються на виробництві керамічної цегли, проте вартість реалізованої продукції у них не перевищує 2 млн грн. У розташуванні вони переважно орієнтуються на сировину (див. рис. 2).

Виробництво цементу, вапна та гіпсових сумімей. Виробництво в'яжучих матеріалів $\epsilon$ одним 3 головних напрямків будівельної індустрії в області, який певною мірою визначає їі промислову спеціалізацію у загальнодержавному масштабі. Ще в 1898 році на базі невеличкого цементного виробництва був побудованим Здолбунівський цементний завод «Волинь», що став одним 3 найпотужніших підприємств по виробництву будівельних матеріалів у всій Волинській губернії. Нині ПАТ «ВолиньЦемент» набуло значного розвитку з приходом на підприємство нового власника - німецької фірми «Дікергофф АГ», яка входить до першої десятки світових виробників цементу та бетону.

Питома вага ПАТ «Волинь-Цемент» на цементному ринку України складає близько $10 \%$. Основними ринками збуту цементу $є$ західні та центральні регіони країни та м. Київ. Доля експорту складає близько 5\%. Основними ринками збуту загально-будівельного цементу (ПЦІІА-Ш-500, ПЦІІА-Ш-400, ПЦІ-500) є такі області: Волинська, Львівська, Тернопільська, Житомирська, Хмельницька, Вінницька, Київська, м.Київ. Основними споживачами спеціальних цементів ПЦТІІ-50 та ПЦТІ-100 є нафто- та газовидобувні підприємства України. Значна частина сировини видобувається самим підприємством, інша (каолін, камінь гіпсовий, граншлак, кек глиноземний) закуповується на внутрішньому ринку.

Обсяги реалізованої продукції у 2014 році становили понад 755 млн грн, займаючи за даним показником п'яту позицію у області і забезпечуючи понад $80 \%$ в.р.п.п. Здолбунівського району, проте підприємство є збитковим (455 млн грн у 2014 році). В 2014 році підприємством було вироблено 952,2 тис тон цементу та 825 тис тон клінкеру.

Виготовлення виробів із бетону, гіпсу та цементу. Підприємства даного напрямку у розміщенні орієнтуються на споживчо-сировинний фактор, тому всі сім виробників зосереджені в Рівному чи поблизу нього, формуючи тісні зв'язки із цементним заводом, що розміщений у м. Здолбунів.

У м. Здолбунів діє ТОВ «Волинь-шифер», проте із запуском лінії з виробництва бруківки у 2008 році, шифер перестали випускати. Пісок підприємство отримує з кар'єрів у Нетішині та Славуті, щебінь постачає Клесівський кар'єр.

Різання, оброблення та оздоблення декоративного та будівельного каменю. У області діє п'ять підприємств даного напрямку, що у розташуванні переважно орієнтуються на сировину, тобто на кар'єри із видобутку будівельного та декоративного каменю.

Отже, Рівненська область характеризується досить значним розвитком такої галузі промисловості, як виробництво будівельних матеріалів. Будівельна промисловість є галуззю спеціалізації даної області. Для ㄲï подальшого розвитку склалися сприятливі передумови: наявність великої кількості покладів неметалевих ресурсів; значні виробничі потужності підприємств вищезазначеної галузі промисловості; постійний попит на будівельну продукцію, як $з$ боку українських підприємств, так і з боку іноземних.

\section{References:}

1. Ecological passport of Rivne region (2014). Official website of the Ministry of Ecology and Natural Resources of Ukraine. Access mode: http://www.menr.gov.ua/protection/protection1/rivnenska (In Ukrainian).

2. Investment map of Rivne region. Access mode: http://investmap.rv.ua (In Ukrainian).

3. İŝk S. Ì., Gladkij O. V. Geografîa promislovih kompleksìv: pidručnik [The geography of industrial complexes: a textbook]. Kyiv, 2011, 375 p. (In Ukrainian). 